\title{
Cluster Demonstration- An Approach to Augment Productivity in Blackgram
}

\author{
G. Porkodi ${ }^{\text {* }}$ and M. Nirmala Devi \\ ${ }^{1}(S S \& A C)$, Krishi Vigyan Kendra, TNAU, Vridhachalam, India \\ ${ }^{2}$ (Agricultural Extension), AC\&RI, TNAU, Vazhavachanur, India \\ *Corresponding author
}

Key w o r d s
Blackgram,
productivity,
technologies,
FLD and cluster
approach

\section{Introduction}

Blackgram is one of the major crops cultivated in Cuddalore district in an area of 45000 ha every year. To enhance the blackgram production and productivity in Cuddalore district, Front line demonstrations were carried out as cluster approach by the scientists of Krishi Vigyan Kendra, KVK, Vridhachalam, Cuddalore District. Existing Farmers'

\begin{abstract}
A B S T R A C T
Krishi Vigyan Kendra, Cuddalore District intervened with demonstrations on pulses with cluster approach to increase the production of pulses in Cuddalore district under NFSM-pulse production scheme. The KVK has conducted 50 front line demonstrations in farmer's fields during the year 2015-16 in black gram in an area of 20ha. Front line demonstration is an appropriate means for demonstration as well as transfer of improved agricultural innovations to the farming community. Two cluster villages viz., Melpuliankudi and Agrahram of Kattumanarkoil block were selected for the purpose and the blackgram variety VBN 5 was selected for demonstration. From the demonstrations, an average yield of $5.20 \mathrm{q} \mathrm{ha}^{-1}$ was recorded as against $4.21 \mathrm{q} \mathrm{ha}^{-1}$ from farmers practice and the maximum yield of $5.91 \mathrm{q} \mathrm{ha}^{-1}$ was noticed and a quantity of $1120 \mathrm{~kg}$ of produce was sold as seed to other farmers in the region. Obviously, this can be attributed to improved technology as well as improved variety. The yield levels were considerably low under local practices because of considerable variations in the extent of adoption of recommended package of practices depending upon the amount of risk involved in terms of cost, convenience, skill and knowledge about the concerned practice. The productivity was better over local practice under demonstrations. Hence, cluster approach in disseminating pulses production technologies had an efficient impact on productivity of the crop and this may be considered to be applicable for other crops too.
\end{abstract}


not be attained due to lack of awareness of the varieties, low rate of adoption and low yields of obsoletes varieties, pulses production is mostly from the crop raised under rainfed conditions, cultivation of pulses in marginal lands, limited area of pulses under irrigated conditions, pests and diseases and processing loss These factors limiting the productivity cannot be overlooked. To raise production an effective way of transfer of technology is needed. The efforts should be taken with planning, execution and follow up action of the pulses production technology through front line demonstrations, the present investigation was therefore undertaken to ascertain the importance of demonstrations in pulses production technology for increased yield.

\section{Materials and Methods}

The technologies to be demonstrated for blackgram was identified based on Participatory Rural Appraisal (PRA) technique. A group of farmers were identified based on their participation and feedback received during the preliminary survey and interactive meeting. Frontline demonstrations were conducted by Krishi Vigyan Kendra, Vridhachalam, Cuddalore District in Rabi season in the farmer's fields of cluster villages viz., Melpuliankudi and Agrahram from Kattumanarkoil block during 2015-16. All 50 demonstrations in 20 ha area were conducted by the active participation of farmers with the objective to demonstrate the improved technologies of pulses in selected villages along with farmers practice as control plot. Pre-sowing trainings were organized involving the selected farmers in their village for the crop. Critical inputs were distributed to the farmers. Supply of necessary literature and regular visits for monitoring pest and diseases were made and advisory services were provided to the demo farmers. Finally, field day was conducted involving demonstration holding farmers, other farmers in the village, officials from Department of Agriculture and extension functionaries to demonstrate the success of the technology. Crop yield was recorded from the demonstration and control plots.

The yield data were collected from both the plots of demonstration and farmers practice by random crop cutting method and analyzed. The technology gap and technological index (Samui et al., 2000) were calculated by using following formula.

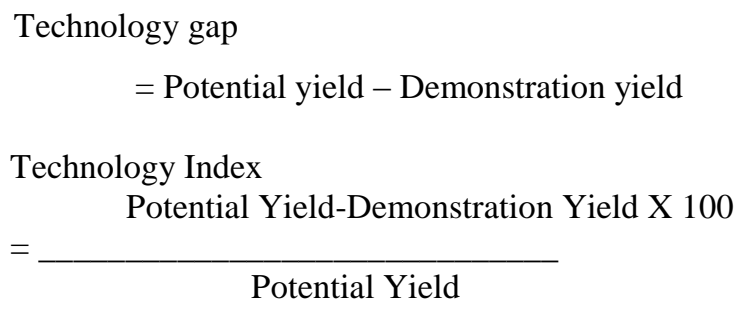

Percent increase yield

Demonstration yield - farmers yield X 100

Farmers yield

Percent increase yield

Demonstration yield - farmers yield X 100

$=$

Farmers yield

\section{Results and Discussion}

The data collected with reference to farmers practice was tabulated against the technology gap (Table 1)

The demonstration plot was intervened with the black gram variety VBN 5, seed treatment with Rhizobium @ 200g per ha of seed and Pseudomonas fluorescens at $10 \mathrm{~g} \mathrm{~kg}-1$ of seed, spraying of pulse wonder $5 \mathrm{~kg}$ per acre at the time of flowering and Setting up of yellow sticky traps @ 5 per acre, setting of 
pheromone traps@5 per acre. The farmers were also imparted with trainings on production technologies of black gram. Periodical visits were made by the subject matter specialists of Krishi Vigyan Kendra and field advisory services on crop management and crop protection were given.
The demo and check plots were observed and monitored periodically and the data were recorded. Field day was organized by inviting participation of the demo farmers, fellow farmers and extension officials form the district. The farmers were encouraged through the visualizing the results of the demo plot.

Table.1 Differences between technological interventions and farmers practices under FLD on blackgram

\begin{tabular}{|c|c|c|c|}
\hline Particulars & $\begin{array}{c}\text { Technological intervention in } \\
\text { FLD }\end{array}$ & Farmers practices & Gap \\
\hline Variety & VBN 5 & Local/own seed & Full gap \\
\hline Seed rate & $20 \mathrm{~kg} / \mathrm{ha}$ & $25 \mathrm{~kg} / \mathrm{ha}$ & High seed rate \\
\hline Seed treatment & $\begin{array}{l}\text { Rhizobium @ } 200 \mathrm{~g} \text { per ha of seed } \\
\text { Pseudomonas fluorescens at } 10 \mathrm{~g} \\
\mathrm{~kg}-1 \text { of seed }\end{array}$ & No seed treatment & Full gap \\
\hline Fertilizer dose & $\begin{array}{l}55 \mathrm{Kg} \text { of urea, } 312 \mathrm{~kg} \text { of Super } \\
\text { phosphate, } 42 \mathrm{~kg} \text { of potash }+ \\
\text { TNAU micronutrient mixture } \\
(\mathrm{MN}) \text { at } 12.5 \mathrm{~kg} \text { per ha }\end{array}$ & No use of fertilizer & Full gap \\
\hline Growth Regulators & $\begin{array}{l}\text { spraying of pulse wonder } 5 \mathrm{~kg} \text { per } \\
\text { acre at the time of flowering }\end{array}$ & $\begin{array}{l}\text { No use of growth } \\
\text { regulators }\end{array}$ & Full gap \\
\hline Weed management & $\begin{array}{l}\text { Pendimithalin @ } 2.5 \mathrm{~L} / \mathrm{ha} \text { and one } \\
\text { hand weeding @ } 20 \mathrm{DAS}\end{array}$ & $\begin{array}{l}\text { Pendimithalin @ } 2.5 \\
\text { L/ha }\end{array}$ & Partial gap \\
\hline Plant protection & $\begin{array}{l}\text { Setting up of yellow sticky traps @ } \\
5 \text { per acre, setting of pheromone } \\
\text { traps@ } 5 \text { per acre }\end{array}$ & Improper measures & Full gap \\
\hline
\end{tabular}

Table.2 Technical Parameters of blackgram under Frontline Demonstration and farmers practice (check) during Rabi season (Pooled data)

\begin{tabular}{|c|c|c|c|c|c|c|c|c|}
\hline \multirow{2}{*}{$\begin{array}{c}\text { Demo } \\
\text { variety }\end{array}$} & \multirow{2}{*}{$\begin{array}{l}\text { No. of } \\
\text { Demos }\end{array}$} & \multirow{2}{*}{$\begin{array}{l}\text { Area } \\
\text { (ha) }\end{array}$} & \multicolumn{2}{|c|}{ Yield (q/ha) } & \multirow{2}{*}{$\begin{array}{l}\% \text { increase } \\
\text { over check }\end{array}$} & \multirow{2}{*}{$\begin{array}{c}\text { Potential } \\
\text { yield }(q / h a)\end{array}$} & \multirow{2}{*}{$\begin{array}{l}\text { Technology } \\
\text { gap (q/ha) }\end{array}$} & \multirow{2}{*}{$\begin{array}{c}\text { Technology } \\
\text { index }(\%)\end{array}$} \\
\hline & & & Demo & Check & & & & \\
\hline VBN 5 & 50 & 20 & 5.20 & 4.21 & 23.51 & 9.00 & 3.8 & 42.22 \\
\hline
\end{tabular}


Table.3 Economic Parameters of blackgram under Frontline Demonstration and farmers practice (check) during Rabi season (Pooled data)

\begin{tabular}{|c|c|c|c|c|c|c|c|c|c|}
\hline \multirow{2}{*}{$\begin{array}{c}\text { Variety } \\
\text { demonstrated }\end{array}$} & \multicolumn{4}{|c|}{ Farmer's Existing plot (Check) } & \multicolumn{4}{|c|}{ Demonstration plot } & \multirow{2}{*}{$\begin{array}{l}\text { Farmers } \\
\text { feedback }\end{array}$} \\
\hline & $\begin{array}{c}\text { Gross } \\
\text { Cost } \\
\text { (Rs/ha) }\end{array}$ & $\begin{array}{l}\text { Gross } \\
\text { return } \\
\text { (Rs/ha) }\end{array}$ & $\begin{array}{c}\text { Net } \\
\text { Return } \\
\text { (Rs/ha) }\end{array}$ & $\begin{array}{l}\text { B:C } \\
\text { Ratio }\end{array}$ & $\begin{array}{c}\text { Gross } \\
\text { Cost } \\
\text { (Rs/ha) }\end{array}$ & $\begin{array}{c}\text { Gross } \\
\text { return } \\
\text { (Rs/ha) }\end{array}$ & $\begin{array}{c}\text { Net } \\
\text { Return } \\
\text { (Rs/ha) }\end{array}$ & $\begin{array}{l}\text { B:C } \\
\text { ratio }\end{array}$ & \\
\hline $\begin{array}{l}\text { VBN } 5 \text { for } 50 \\
\text { demonstration }\end{array}$ & 26150 & 38678 & 12528 & 1.48 & 29145 & 48944 & 19798 & 1.67 & $\begin{array}{l}\text { No of pods } \\
\text { per plant is } \\
\text { more than the } \\
\text { farmer } \\
\text { practice }\end{array}$ \\
\hline
\end{tabular}

Table.4 Socio-economic impact parameters of blackgram under Frontline Demonstration and farmers practice (check) during Rabi season

\begin{tabular}{|l|l|l|l|l|l|l|l|l|}
\hline $\begin{array}{l}\text { S. } \\
\text { No. }\end{array}$ & $\begin{array}{c}\text { Crop and } \\
\text { variety } \\
\text { Demonstrated }\end{array}$ & $\begin{array}{c}\text { Total } \\
\text { Produce } \\
\text { Obtained } \\
\text { (kg) }\end{array}$ & $\begin{array}{c}\text { Produce sold } \\
(\mathbf{k g} / \text { househol } \\
\mathbf{d})\end{array}$ & $\begin{array}{c}\text { Selling } \\
\text { Rate } \\
\text { (Rs/kg) }\end{array}$ & $\begin{array}{c}\text { Produce } \\
\text { used for } \\
\text { own } \\
\text { sowing } \\
\text { (kg) }\end{array}$ & $\begin{array}{c}\text { Produce } \\
\text { distributed } \\
\text { to other } \\
\text { farmers } \\
\text { (kg) }\end{array}$ & $\begin{array}{c}\text { Purpose for } \\
\text { which } \\
\text { income } \\
\text { gained was } \\
\text { utilized }\end{array}$ & $\begin{array}{c}\text { Employme } \\
\text { nt } \\
\text { Generated } \\
\text { (Mandays/ } \\
\text { house hold) }\end{array}$ \\
\hline $\mathbf{1}$ & $\begin{array}{l}\text { Blackgram } \\
\text { VBN 5 }\end{array}$ & 15464 & 910 & 96.00 & 3750 & 4500 & $\begin{array}{l}\text { Livelihood, } \\
\text { Education } \\
\text { purpose }\end{array}$ & 22 \\
\hline
\end{tabular}

Average yield recorded in blackgram under rainfed situation was ranged 4.50 to $5.91 \mathrm{q} / \mathrm{ha}$ with an average of $5.20 \mathrm{q} / \mathrm{ha}$ in FLD plots which was more than check plot wherein, the average of $4.21 \mathrm{q}$ per ha (Table 2). The results indicated that the frontline demonstrations gave good impact over the farming community of Cuddalore district as they were motivated by the new agricultural technologies applied in the FLD plots. The economics of the Front Line Demonstration showed that the highest net return (Rs. 19798) with the B:C ratio of 1.67 when compared with farmers practice (Rs. 12528) with the $\mathrm{B}: \mathrm{C}$ ratio of 1.48 (Table 3 ).

It is concluded that the FLD programme is an effective tool for increasing the production and productivity of pulses and changing the knowledge, attitude and skill of farmers. Use of improved method of blackgram cultivation can reduce the technology gap to a considerable extent thus leading to increase productivity of blackgram in the district. Through FLD an average yield of $5.20 \mathrm{q} \mathrm{ha}^{-1}$ was recorded as against $4.21 \mathrm{q} \mathrm{ha}^{-1}$ from farmers practice and the maximum yield of $5.91 \mathrm{q} \mathrm{ha}^{-1}$ was noticed. These demonstrations also built the relationship and confidence between farmers and scientists.

The beneficiary farmers of FLDs also play an important role as source of information and quality seeds for wider dissemination and horizontal spread of the high yielding varieties of pulses to other farmers. Technology index which shows the feasibility of the technology demonstrated has depicted good performance of the intervention. 


\section{References}

Samui, S. K., Maitra, S., Roy, D. K., Mandal, A. K. and Saha, D. (2000). Evaluation of front line demonstration on groundnut. J Indian Soc. Coastal Agric. Res., 18(2): 180-183.

\section{How to cite this article:}

Porkodi, G. and Nirmala Devi, M. 2019. Cluster Demonstration- An Approach to Augment Productivity in Blackgram. Int.J.Curr.Microbiol.App.Sci. 8(09): 1352-1356.

doi: https://doi.org/10.20546/ijcmas.2019.809.155 